\title{
Risk of hypertension in Yozgat Province, Central Anatolia: application of Framingham Hypertension Prediction Risk Score
}

\author{
M. Kilic, ${ }^{1}$ H. Ede ${ }^{2}$ and A.I. Kilic ${ }^{3}$
}

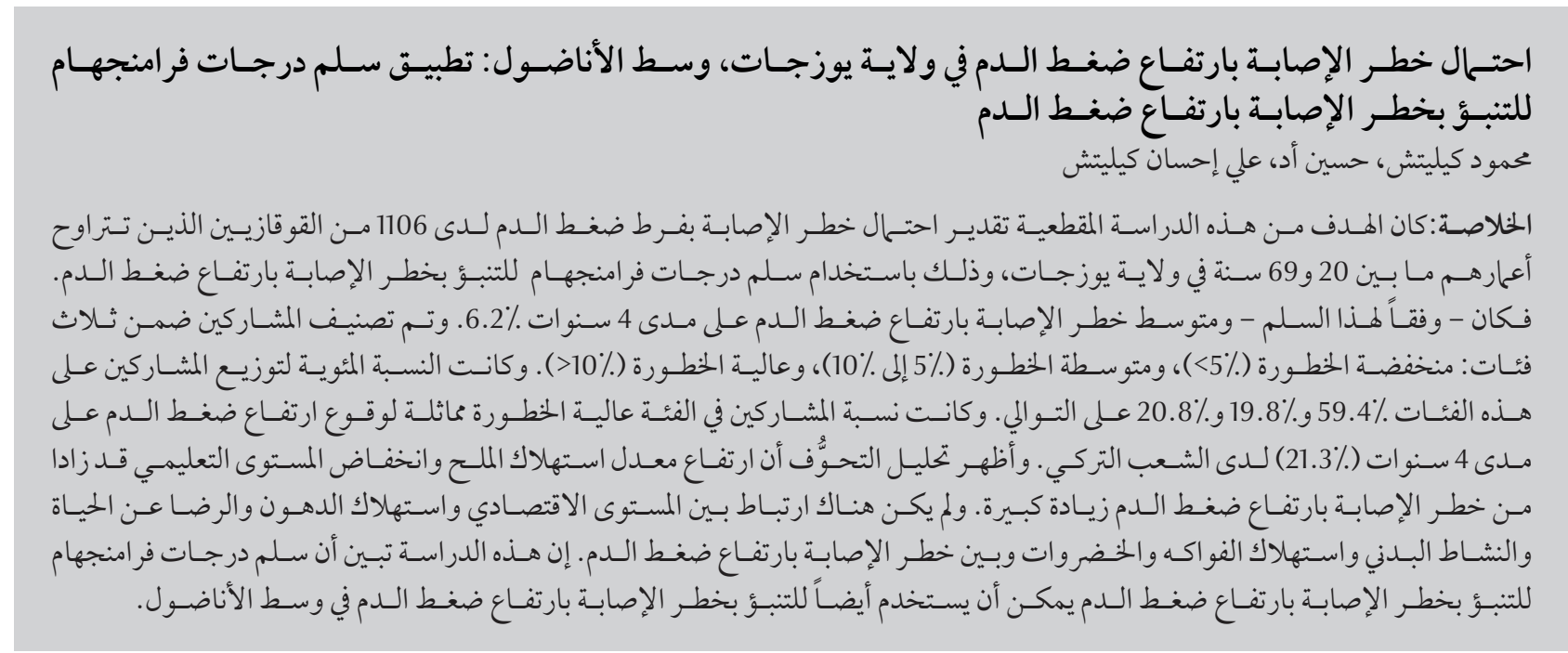

ABSTRACT The aim of this cross-sectional study was to estimate the risk of hypertension in 1106 Caucasian individuals aged 20-69 years in Yozgat Province, using the Framingham Hypertension Risk Prediction Score (FHRPS). According to FHRPS, average risk of developing hypertension over 4 years was $6.2 \%$. The participants were classified into low- $(<5 \%)$, moderate- (5\% to $10 \%)$ and high- $(>10 \%)$ risk groups. The percentage of participants that fell into these groups was $59.4 \%, 19.8 \%$ and $20.8 \%$ respectively. The proportion of participants in the high-risk group was similar to the 4-year incidence of hypertension (21.3\%) in the Turkish population. Regression analysis showed that high salt consumption and low educational level significantly increased the risk of hypertension. Economic level, fat consumption, life satisfaction, physical activity, and fruit and vegetable consumption were not correlated with risk of hypertension. This study shows that FHRPS can also be used for predicting risk of hypertension in Central Anatolia.

\begin{abstract}
Risques d'hypertension dans la Province de Yozgat en Anatolie centrale : application de l'indice de risque de Framingham pour la prédiction de l'hypertension

RÉSUMÉ La présente étude transversale avait pour objectif d'estimer le risque d'hypertension de 1106 Caucasiens âgés de 20 à 69 ans dans la province de Yozgat, sur la base de l'indice de risque de Framingham pour la prédiction de I'hypertension. Selon l'indice, le risque moyen de développer une hypertension sur 4 ans était de 6,2 \%. Les participants ont été classés en groupes à risque faible $(<5 \%)$, modéré ( $5 \%$ à $10 \%)$ et élevé $(>10 \%)$. Les pourcentages de participants qui correspondaient à ces groupes étaient de 59,4\%, 19,8 \% et 20,8 \% respectivement. La proportion de participants dans le groupe à risque élevé était similaire à l'incidence de l'hypertension sur 4 ans $(21,3 \%)$ dans la population turque. L'analyse de régression a montré qu'une consommation excessive de sel et qu'un faible niveau d'éducation augmentaient considérablement le risque d'hypertension. Le niveau économique, la consommation de graisse, le niveau de satisfaction dans la vie, l'activité physique, et la consommation de fruits et de légumes n'étaient pas corrélés au risque d'hypertension. L'étude montre que l'indice de Framingham peut aussi être utilisé pour la prédiction du risque d'hypertension en Anatolie centrale.
\end{abstract}




\section{Introduction}

About $63 \%$ of deaths result from noncommunicable diseases and one of the most important is cardiovascular disease. Eighty-percent of deaths caused by noncommunicable diseases occur in countries with low and middle income. According to the 2010 World Health Organization (WHO) Global Status Report on Noncommunicable Diseases, hypertension is a leading risk factor for chronic diseases and related deaths. The number of patients with hypertension increased from 600 million in 1980 to $~ 1$ billion in 2008 worldwide. In parallel to this finding, prevalence of hypertension among people aged $>25$ years is nearly $40 \%$ and $\sim 7.5$ million people die from hypertension-related diseases annually, which accounts for $12.8 \%$ of all deaths. Hypertension is a major risk factor for coronary heart disease and stroke, and comprises $3.7 \%$ of disability-adjusted life years (DALYs) (1).

According to the Turkey Burden of Disease Study, $79 \%$ of all deaths are caused by noncommunicable diseases. In Turkey, hypertension is a leading cause of DALYs among 7 associated risk factors. It is estimated that tout of 4 deaths, one could be prevented if hypertension were controlled (2). The American College of Cardiology advises that blood pressure (BP) should be measured once every 2 years in adults with normotension and annually in prehypertensive individuals (3). It is reported that $86 \%$ of outpatients attending any primary healthcare centre in Yozgat Province measured their BP once in 2 years (4).

The prevalence and awareness of hypertension in developing countries are $32.2 \%$ and $40.6 \%$ for men and $30.5 \%$ and $52.7 \%$ for women, respectively. In comparison, these values in developed countries are $40.8 \%$ and $49.2 \%$ for men and $33.0 \%$ and $61.7 \%$ for women (5). According to the PatenT2 study of the Turkish Society of Hypertension and Kidney Disease (6), prevalence of hypertension among people aged $>18$ years in Turkey was $30.3 \%$ in 2012. This compares with $35.1 \%$ in the SALTurk study in 2008 (7). Prevalence of hypertension in Finland decreased from 63.3\% to $52.1 \%$ among men and from $48.1 \%$ to $33.6 \%$ among women, after measures were taken from 1982 to 2007 (8). Awareness of hypertension ranges between $40.7 \%$ and $49 \%$ according to the prevalence studies held in Turkey $(7,9)$. Awareness of hypertension is higher among men than women in developing (52.7\% vs $40.6 \%)$ and developed countries (61.7\% vs $49.2 \%)$ (5). Awareness of hypertension is vital for adherence to antihypertensive medication. Blood pressure is only controlled in $28.7 \%$ of patients with hypertension in Turkey (6), compared with $29.6 \%$ of men and $34 \%$ of women in developing countries, and $33.2 \%$ of men and $38.4 \%$ of women in developed countries (5). According to the Turkish incidence of hypertension (HinT) study, the 4-year incidence of hypertension was $21.3 \%$ (10).

The lifelong risk of developing hypertension among individuals aged 55 65 years was $90 \%$ in the Framingham Heart Study (FHS) (11). That study in the United States (US) reported that the risk of developing hypertension was $35.8 \%$ for men until age 65 years and $69.2 \%$ until age 81 years (12). Age, gender, cigarette smoking, family history of hypertension and body mass index are risk factors for hypertension according to FHS (13).

To date, no study has estimated the risk of hypertension in Turkey. The aim of this study was to estimate the risk of hypertension in the community using the Framingham Hypertension Risk Prediction Score (FHRPS).

\section{Methods}

\section{Study population}

This was a cross-sectional study of individuals aged 20-69 years residing in Yozgat Province between March and
May 2011. The records of the Turkish Statistical Institute for 2010 showed 75,012 people living in Yozgat Province (14) and 51,000 residents were aged $\geq 18$ years. The random systematic sampling method was used when selecting the sample. One out of 25 houses and workplaces was included in the study sample. When there were $\leq 25$ employees in a workplace, all of them were enrolled. When there were $>25$ people, only 25 of them were included through simple random sampling. The data were collected through BP measurements and a literature-based $(13,15)$ questionnaire that was prepared by the investigator. The questionnaire was administered to the participants by the nurse interviewers.

We excluded participants who had prevalent hypertension [systolic BP (SBP) $\geq 140 \mathrm{mmHg}$ or diastolic BP (DBP) $\geq 90 \mathrm{mmHg}$, cardiovascular disease, diabetes mellitus and a history of any degree of renal failure. After we applied the exclusion criteria, 1106 of 1837 individuals remained eligible for analysis.

\section{Survey}

Presence of hypertension among parents, cigarette smoking, salt and fat consumption, educational status, income, quality of life, physical activity, and fruit and vegetable consumption were all recorded in the questionnaire. Informed consent was obtained from each participant. Ethical approval was provided by the local ethical committee and the study was carried out in accordance with the Declaration of Helsinki.

Trained health workers blinded to the study measured body height and weight of study participants in the erect position without shoes and wearing casual clothing, using a digital electronic scale. BMI values were classified according to WHO criteria (16). A trained health worker blinded to the study measured BP from the right and left arms of the participants in the sitting position after a $10-$ min rest. BP 
was measured twice at a 5-min interval. SBP and DBP were recorded at the 1 st and 5th Korotkoff phases, respectively, using a mercury sphygmomanometer. The average of $4 \mathrm{BP}$ measurements was used for analysis. BP was classified according to the Seventh Report of the Joint National Committee on Prevention, Detection, Evaluation, and Treatment of High Blood Pressure as follows: normal BP: SBP $<120 \mathrm{mmHg}$ and $\mathrm{DBP}<80 \mathrm{mmHg}$; prehypertension: SBP $120-139 \mathrm{mmHg}$ or DBP 80-89 mmHg; hypertension: SBP $\geq$ $140 \mathrm{mmHg}$ or $\mathrm{DBP} \geq 90 \mathrm{mmHg}(17)$.

\section{Calculation of hypertension risk prediction score}

The hypertension risk prediction score for each individual was calculated using the FHRPS formula described by Parikh et al. (13) using a ready-made Microsoft Excel program downloaded from https://www.framinghamheartstudy.org/risk-functions/hypertension/ index.php\#. They found that age, gender, SBP, DBP, BMI, smoking, history of parental hypertension and DBP values corrected for age were significantly important in predicting development of hypertension (13). Thus, hypertension risk score was calculated by coding: gender $($ male $=0$, female $=1)$, age, SBP, DBP, BMI, smoking status (current smoker $=1$, non-smoker $=0$ ) and presence of parental hypertension (none $=0,1$ parent has hypertension $=1$, both have hypertension $=2$ ). The $\beta$ coefficient of risk predictors was as follows: age, -0.15641 ; gender, -0.20293 ; BMI, -0.03388; SBP, -0,0593; DBP, $-0,12847$; cigarette smoking, $-0,19073$; history of parental hypertension, -0.16612 ; DBP values corrected for age, 0.00162 . The FHRPS formula was validated and found to be statistically excellent in a study held in the United Kingdom (UK) (18). Hypertension risk prediction score was calculated separately as an estimated risk and optimal risk for 1,2 and 4 years. Estimated risk indicated real risk of the individuals and was calculated in relation to the individual's own parameters. Optimal risk indicated risk of individuals at the same age and gender with BMI $<25$ $\mathrm{kg} / \mathrm{m}^{2}$, no smoking, $\mathrm{SBP}<120 \mathrm{mmHg}$, $\mathrm{DBP}<80 \mathrm{mmHg}$ and without parental history of hypertension. Estimated risk and optimal risk were calculated by the formula automatically. A difference in 4-year estimated risk and optimal risk was accepted as a risk difference. Estimated risk and risk difference values were classified into low risk if $<5 \%$; moderate risk if between 5 and $10 \%$ and high risk if $>10 \%$ (13).

The data were analysed with SPSS version 15.0 software (SPSS, Chicago, IL, USA). Statistical analyses were carried out by $\chi^{2}$ test, analysis of variance (ANOVA) and multivariate linear regression analysis (19). Factors that were not in the formula but had the potential to affect indirectly parameters related to hypertension were also included in the analyses. Among these independent variables that were taken as ordinal variables, the effect of educational and economic status, quality of the life, and salt and fat consumptions were categorized using a 5-point Likert-type scale model. The effect of physical activity, and fruit and vegetable consumption were categorized using a 3-point Likert-type scale model. All these ordinal variables were coded as dummy variables.

\section{Results}

Five hundred and seventy-six (51.2\%) participants were female. The mean age was $35.1 \pm 9.4$ years and $29.7 \%$ of all participants were $<30$ years old. Thirty-seven point seven percent of participants were cigarette smokers; $23.2 \%$ claimed that 1 or both parents had hypertension; $35.5 \%$ were prehypertensive; and $37.9 \%$ were overweight, while $18.4 \%$ were obese (Table 1).

After calculating hypertension risk prediction score, average 1,2 and 4-year estimated risk values and their 95\% confidence intervals (CIs) were as follows: $1.4 \%(1.25-1.45 \%), 2.9 \%$ (2.71-3.13\%) and 6.2\% (5.73-6.59\%), respectively. Average risk differences (95\% CI) were as follows: $1.0 \%$ (0.92-1.11\%), 2.2\% (1.97-2.37\%) and $4.5 \%$ (4.10-4.91\%), respectively ( $\mathrm{Ta}-$ ble 2). Characteristics of participants with high 4-year estimated risk scores were determined to be age $\geq 50$ years (13.4\%), prehypertension (13.3\%), obesity (12.1\%), history of hypertension in both parents (10.2\%), current cigarette smoking (6.3\%) (Table 1).

The frequencies of low, moderate and high 4-year estimated risk scores were $59.4 \%, 19.8 \%$ and $20.8 \%$, respectively. The number of participants with moderate 4-year estimated risk score was 4 times more than the number with moderate 1-year estimated risk score (Table 3). The number of participants with high 4-year estimated risk score was 20 times more than the number of participants with high 1-year estimated risk score (Table 3). The frequencies of low, moderate and high 4-year risk difference score were $68.7 \%, 13.8 \%$ and $17.4 \%$, respectively.

Among the risk predictors that were thought to have a potential effect on hypertension risk prediction, only educational status had a significant relationship with 4-year estimated risk. Average 4-year estimated risk score was significantly correlated with educational status, income and salt consumption, but fat consumption, quality of life and fruit and vegetable consumption were not (Table 3). Educational status was not distributed homogeneously according to Levene's test, thus the Tamhane's $\mathrm{T} 2$ test was used for post-ANOVA evaluation. Accordingly, there were no differences among participants with secondary school education, undergraduate education and bachelor's degree $(P>0.05)$. However, there was a significant difference between the participants with elementary school or lower education and those 


\begin{tabular}{|c|c|c|c|c|c|}
\hline \multirow[t]{2}{*}{ Risk predictors } & \multirow[b]{2}{*}{$n(\%)$} & \multicolumn{2}{|c|}{ ER } & \multicolumn{2}{|c|}{ RD } \\
\hline & & 1-year & 4-year & 1-year & 4-year \\
\hline \multicolumn{6}{|l|}{ Gender } \\
\hline Male & $530(47.9)$ & $1.4(1.3-1.5)$ & $6.5(5.9-7.0)$ & $1.1(1.0-1.2)$ & $4.9(4.4-5.4)$ \\
\hline Female & $576(52.1)$ & $1.3(1.1-1.5)$ & $5.9(5.2-6.5)$ & $0.9(0.8-1.1)$ & $4.2(3.5-4.8)$ \\
\hline \multicolumn{6}{|l|}{ Age group (years) } \\
\hline $1-29$ & $328(29.7)$ & $0.6(0.5-0.7)$ & $2.9(2.5-3.3)$ & $0.4(0.3-0.5)$ & $1.9(1.6-2.3)$ \\
\hline $30-39$ & $447(40.4)$ & $1.1(1.0-1.2)$ & $5.0(4.5-5.6)$ & $0.8(0.7-0.9)$ & $3.3(3.1-4.2)$ \\
\hline $40-49$ & $248(22.4)$ & $2.2(2.0-2.5)$ & $10.1(9.0-11.1)$ & $1.8(1.5-2.0)$ & $7.9(6.8-8.9)$ \\
\hline$\geq 50$ & $83(7.5)$ & $3.0(2.5-3.6)$ & $13.4(11.0-15.7)$ & $2.2(1.6-2.8)$ & $9.4(7.1-11.7)$ \\
\hline \multicolumn{6}{|c|}{ Body mass index $\left(\mathrm{kg} / \mathrm{m}^{2}\right)$} \\
\hline$<25$ & $484(43.8)$ & $0.7(0.7-0.8)$ & $3.5(3.1-3.9)$ & $0.5(0.4-0.5)$ & $2.1(1.8-2.5)$ \\
\hline $25-29.9$ & $419(37.9)$ & $1.4(1.2-1.5)$ & $6.3(5.7-7.0)$ & $1.0(0.9-1.2)$ & $4.6(4.0-5.3)$ \\
\hline$\geq 30$ & $203(18.4)$ & $2.7(2.4-3.0)$ & $12.1(10.7-13.4)$ & $2.2(1.9-2.6)$ & $9.9(8.5-11.2)$ \\
\hline \multicolumn{6}{|l|}{ Blood pressure } \\
\hline Normal & $713(64.5)$ & $0.5(0.4-0.5)$ & $2.3(2.2-2.5)$ & $0.2(0.1-0.2)$ & $0.7(0.6-0.9)$ \\
\hline Prehypertension & $393(35.5)$ & $3.0(2.8-3.2)$ & $13.3(12.5-14.1)$ & $2.6(2.4-2.8)$ & 11.4(10.7-12.1) \\
\hline \multicolumn{6}{|l|}{ Cigarette smoking } \\
\hline Current smoker & $417(37.7)$ & $1.4(1.2-1.5)$ & $6.3(5.7-7.0)$ & $1.1(0.9-1.2)$ & $4.7(4.1-5.4)$ \\
\hline Ex-smoker & $135(12.2)$ & $1.5(1.2-1.7)$ & $6.4(5.4-7.9)$ & $1.1(0.8-1.4)$ & $4.8(3.6-6.0)$ \\
\hline Non-smoker & $554(50.1)$ & $1.3(1.2-1.4)$ & $5.9(5.3-6.5)$ & $1.0(0.8-1.1)$ & $4.3(3.7-4.8)$ \\
\hline \multicolumn{6}{|c|}{ Family history of hypertension } \\
\hline None & $849(76.8)$ & $1.2(1.1-1.3)$ & $5.5(5.1-5.9)$ & $0.9(0.8-0.9)$ & $3.8(3.4-4.3)$ \\
\hline One of parents & $210(19.0)$ & $1.8(1.5-2.0)$ & $7.9(6.7-9.1)$ & $1.4(1.2-1.7)$ & $6.3(5.2-7.4)$ \\
\hline Both parents & $47(4.2)$ & $2.3(1.6-3.0)$ & $10.2(7.0-13.3)$ & $1.9(1.2-1.6)$ & $8.3(5.4-11.3)$ \\
\hline Total & $1106(100.0)$ & $1.4(1.3-1.5)$ & $6.2(5.7-6.6)$ & $1.0(0.9-1.1)$ & $4.5(4.1-4.9)$ \\
\hline
\end{tabular}

Results are expressed as mean \% (95\% confidence interval).

\begin{tabular}{|c|c|c|c|}
\hline Risk levels & ER & OR & RD \\
\hline \multicolumn{4}{|l|}{ 1-year } \\
\hline Very low risk (< 1.0\%) & $637(57.6)$ & $1088(98.4)$ & $733(66.3)$ \\
\hline Low risk (1.0-4.9\%) & $418(37.8)$ & $18(1.6)$ & $330(29.8)$ \\
\hline Moderate risk (5.0-10.0\%) & $50(4.5)$ & $0(0.0)$ & $43(3.9)$ \\
\hline High risk (> 10.0\%) & $1(0.1)$ & $0(0.0)$ & $0(0.0)$ \\
\hline Mean $(95 \% \mathrm{Cl})$ & $1.4(1.25-1.45)$ & $0.3(0.33-0.35)$ & $1.0(0.92-1.11)$ \\
\hline \multicolumn{4}{|l|}{ 2-year } \\
\hline Very low risk (< $1.0 \%)$ & $421(38.1)$ & $846(76.5)$ & $575(52.0)$ \\
\hline Low risk (1.0-4.9\%) & $460(41.6)$ & $260(23.5)$ & $346(31.3)$ \\
\hline Moderate risk (5.0-10.0\%) & $161(14.6)$ & $0(0.0)$ & $138(12.5)$ \\
\hline High risk (> 10.0\%) & $64(5.7)$ & $0(0.0)$ & $47(4.2)$ \\
\hline Mean $(95 \% \mathrm{Cl})$ & $2.9(2.71-3.13)$ & $0.8(0.73-0.78)$ & $2.2(1.97-2.37)$ \\
\hline \multicolumn{4}{|l|}{ 4-year } \\
\hline Very low risk (< 1.0\%) & $266(24.1)$ & $214(19.3)$ & $467(42.2)$ \\
\hline Low risk (1.0-4.9\%) & $391(35.4)$ & $876(79.2)$ & $293(26.5)$ \\
\hline Moderate risk (5.0-10.0\%) & 219 (19.8) & $16(1.4)$ & $153(13.8)$ \\
\hline High risk (> 10.0\%) & $230(20.8)$ & $0(0.0)$ & $193(17.4)$ \\
\hline Mean $(95 \% \mathrm{Cl})$ & $6.2(5.73-6.59)$ & $1.6(1.59-1.70)$ & $4.5(4.10-4.91)$ \\
\hline Total & $1106(100.0)$ & $1106(100.0)$ & $1106(100.0)$ \\
\hline
\end{tabular}

Results expressed as No. (\%). Cl= confidence interval 


\begin{tabular}{|c|c|c|c|c|c|}
\hline \multirow[t]{2}{*}{ Correlates } & Total & $\begin{array}{l}\text { Low risk } \\
(<5 \%)\end{array}$ & $\begin{array}{c}\text { Moderate risk } \\
(5-10 \%)\end{array}$ & $\begin{array}{l}\text { High risk } \\
(>10 \%)\end{array}$ & ER \\
\hline & No. (\%) & No. (\%) & No. (\%) & No. (\%) & Mean (SD) \\
\hline \multicolumn{6}{|l|}{ Educational status } \\
\hline$\leq$ Elementary school & $281(25.4)$ & $119(42.3)$ & $59(21.0)$ & $103(36.7)$ & $9.7(9.4)$ \\
\hline Primary school & 143 (12.9) & $70(49.0)$ & $33(23.1)$ & $40(28.0)$ & $7.3(7.5)$ \\
\hline Secondary school & $248(22.4)$ & $164(66.1)$ & $54(21.8)$ & $30(12.1)$ & $4.7(5.8)$ \\
\hline Undergraduate & $131(11.8)$ & $90(68.7)$ & 18 (13.7) & $23(17.6)$ & $4.8(5.6)$ \\
\hline \multirow[t]{2}{*}{ Graduate } & $303(27.4)$ & $214(70.6)$ & $55(18.2)$ & $34(11.2)$ & $4.1(4.9)$ \\
\hline & & & $\chi^{2}=91.5, P<0.001$ & & $F=30.8, P<0.001$ \\
\hline \multicolumn{6}{|l|}{ Economic status } \\
\hline Good income & $255(23.1)$ & $165(64.7)$ & 49 (19.2) & $41(16.1)$ & $4.8(5.7)$ \\
\hline Moderate income & $743(67.2)$ & $434(58.4)$ & 148 (19.9) & $161(21.7)$ & $6.5(7.5)$ \\
\hline \multirow[t]{2}{*}{ Poor income } & $108(9.8)$ & $58(53.7)$ & $22(20.4)$ & $28(25.9)$ & $7.3(8.3)$ \\
\hline & & & $\chi^{2}=6.4, P=0.174$ & & $F=6.3, P=0.002$ \\
\hline \multicolumn{6}{|l|}{ Quality of life } \\
\hline Satisfied enough & $821(74.2)$ & $483(58.8)$ & 163 (19.9) & $175(21.3)$ & $6.1(7.2)$ \\
\hline \multirow[t]{2}{*}{ Moderately or not satisfied } & $285(25.8)$ & $174(61.1)$ & $56(19.6)$ & $55(19.3)$ & $6.3(7.5)$ \\
\hline & & & $\chi^{2}=0.6, P=0.743$ & & $F=0.3, P=0.728$ \\
\hline \multicolumn{6}{|l|}{ Fruit/vegetable consumption } \\
\hline$<1$ meal per day & $239(21.6)$ & $139(58.2)$ & $43(18.0)$ & $57(23.8)$ & $6.6(7.6)$ \\
\hline 1-2 meals per day & $548(49.5)$ & $332(60.6)$ & $105(19.2)$ & $111(20.3)$ & $6.0(7.1)$ \\
\hline \multirow[t]{2}{*}{$\geq 3$ meals per day } & 319 (28.8) & $186(58.3)$ & $71(22.3)$ & $62(19.4)$ & $6.1(7.3)$ \\
\hline & & & $\chi^{2}=3.2, P=0.530$ & & $F=0.5, P=0.609$ \\
\hline \multicolumn{6}{|l|}{ Physical activity } \\
\hline None & $572(51.7)$ & $328(57.3)$ & 114 (19.9) & $130(22.7)$ & $6.6(7.7)$ \\
\hline Insufficient & $275(24.9)$ & $170(61.8)$ & $59(21.5)$ & $46(16.7)$ & $5.6(6.9)$ \\
\hline \multirow[t]{2}{*}{ Sufficient } & $259(23.4)$ & $159(61.4)$ & $46(17.8)$ & $54(20.8)$ & $5.7(6.6)$ \\
\hline & & & $\chi^{2}=5.0, P=0.288$ & & $F=2.3, P=0.101$ \\
\hline \multicolumn{6}{|l|}{ Salt consumption } \\
\hline High-salt content & 209 (18.9) & $134(64.1)$ & $43(20.6)$ & $32(15.3)$ & $5.0(5.8)$ \\
\hline Moderate-salt content & $672(60.8)$ & $392(58.3)$ & $130(19.3)$ & $150(22.3)$ & $6.4(7.5)$ \\
\hline \multirow[t]{2}{*}{ Low-salt content/no salt } & $225(20.3)$ & $131(58.2)$ & $46(20.4)$ & $48(21.3)$ & $6.5(7.8)$ \\
\hline & & & $\chi^{2}=4.9, P=0.292$ & & $F=3.2, P=0.043$ \\
\hline \multicolumn{6}{|l|}{ Fat consumption } \\
\hline High fat content & $129(11.7)$ & $76(58.9)$ & $20(15.5)$ & $33(25.6)$ & $7.1(8.7)$ \\
\hline Moderate fat content & $743(67.2)$ & $448(60.3)$ & $147(19.8)$ & 148 (19.9) & $5.9(6.7)$ \\
\hline \multirow[t]{2}{*}{ Low fat content/no fat } & $234(21.2)$ & $133(56.8)$ & $52(22.2)$ & $49(20.9)$ & $6.6(8.1)$ \\
\hline & & & $\chi^{2}=4.0, P=0.412$ & & $F=2.1, P=0.129$ \\
\hline Total & 1106 (100.0) & $657(59.4)$ & 219 (19.8) & $230(20.8)$ & $6.2(7.3)$ \\
\hline
\end{tabular}

$E R=$ estimated risk; FHRPS = Framingham Hypertension Risk Prediction Score $;$ SD = standard deviation

with primary school education, and both educational levels differed significantly from the other educational levels $(P<0.05)$. In multivariate linear regression analyses, lower educational level and higher salt consumption were significantly associated with a higher hypertension prediction risk score. However, the effect of these variables $\left(R^{2}\right)$ on hypertension prediction risk was $<1 \%$ (Table 4$)$. There was an inverse relationship between educational status and salt consumption $(r=-0.32, P<0.001)$. When age was included in the regression analysis, educational status was still found to be significant in calculating hypertension prediction risk score. 


\section{Discussion}

There are few studies dealing with community-based hypertension risk prediction. In this study, we aimed at predicting hypertension risk using the FHRPS method among adults without previous heart disease, diabetes, any renal failure or hypertension.

The frequency of patients with 4-year moderate hypertension risk prediction in our study $(19.8 \%)$ was similar to that of patients enrolled in FHS (19\%), while frequency of highrisk patients (20.8\%) was lower than that in FHS (47\%) (13). This might have resulted from younger average age (35 years) and lower frequency of family history for hypertension (23.2\%) in our study compared to FHS (42 years and $60 \%$, respectively). In our study, the frequency of the population with 4-year hypertension risk prediction (20.8\%) was similar to that of patients (21.3\%) enrolled in the HinT study (10).

Average 4-year hypertension risk prediction in participants with prehypertension at the time of measurement was 5.8 times higher than that of those with normal BP. In a validation study of FHRPS held in England, the relevant value was 5.7 for 5-year predicted hypertension risk (18). Our results were similar to those of the study held in England.

In a meta-analysis, it was found that patients with prehypertension had a greater risk of cardiovascular disease, coronary heart disease and stroke compared to patients with normal BP $(20,21)$. The four-year average hypertension risk of participants with a history of hypertension in both parents (10.2\%) was nearly 2 times higher than that of participants without a history in both parents (5.5\%) (Table 1).

A study from the US revealed that $60.4 \%$ of men with hypertension had a family history of hypertension in at least 1 parent and men with a family history had a 6.2 times higher risk of developing hypertension before age 55 years compared with those without a family history (12). According to FHS, 10-year risk for developing hypertension in men and women $>55$ years old was $56 \%$ and $52 \%$, respectively (11). Additionally, the CARDIA study (22) from the US revealed that 5- and 20-year cumulative incidence of hypertension in people aged 18-30 years was $3.2 \%$ and $25.7 \%$, respectively (Caucasian men had an incidence of $3.2 \%$ and $21.4 \%$, respectively vs $1 \%$ and $12.3 \%$ in women). In the Brazilian population aged $18-30$ years, the 5.6-year incidence of hypertension was $21.5 \%$ (23) and the 5-year incidence in South Korea was $22.9 \%$ (24). In our study, the 4-year risk of hypertension $(20.8 \%)$ was similar to the levels detected in Brazil and South Korea. In the Whitehall II trial in the UK, testing validation of FHRPS, the predicted hypertension risk was similar to the observed incidence of hypertension (18). A similar situation was found in our study, in which the predicted hypertension risk was similar to the observed incidence of hypertension in the HinT study (10).

Average salt consumption in Turkey was found to be $14.82 \mathrm{~g} /$ day (25). Excessive salt intake leads to high BP and uncontrolled hypertension. With a mean reduction of $4.4 \mathrm{~g} /$ day salt intake, there would be mean changes of $-4.18 \mathrm{~mm} \mathrm{Hg}$ for SBP and $-2.06 \mathrm{~mm}$ $\mathrm{Hg}$ for DBP (26). In our study, we also confirmed that participants with high salt consumption had a high hypertension risk score (Table 4). Educational level was shown to be important in medication adherence, better lifestyle modification, and greater awareness and control of hypertension. Therefore, educational status is important in follow-up of hypertension for better clinical outcomes. In our study, we found that low educational status was significantly related to high hypertension risk score. We suggest that social policies should be developed to improve awareness about hypertension among people with low educational status and high hypertension risk score.

There were some limitations to our study. The study was carried out in an urban region and did not therefore

\begin{tabular}{|c|c|c|c|c|c|}
\hline Independent variables & $\beta$ & $95 \% \mathrm{Cl}$ & $t$ & $P$ & Correlation $r$ \\
\hline (Constant) & 9.866 & (6.827 to 12.905$)$ & 6.370 & $<0.001$ & \\
\hline Education status $^{\mathrm{a}}$ & -1.528 & $(-1.832$ to -1.224$)$ & -9.863 & $<0.001$ & -0.295 \\
\hline Economic status ${ }^{\mathrm{a}}$ & 0.345 & $(-0.066$ to 0.757$)$ & 1.648 & 0.100 & -0.090 \\
\hline Quality of life ${ }^{a}$ & 0.371 & $(-0.180$ to 0.922$)$ & 1.320 & 0.187 & -0.010 \\
\hline Salt consumption ${ }^{\mathrm{a}}$ & 0.564 & (0.002 to 1.126$)$ & 1.969 & 0.049 & 0.064 \\
\hline Fat consumption ${ }^{\mathrm{a}}$ & -0.046 & $(-0.734$ to 0.643$)$ & -0.130 & 0.897 & 0.011 \\
\hline Physical activity ${ }^{\mathrm{b}}$ & -0.336 & $(-0.845$ to 0.174$)$ & -1.293 & 0.196 & -0.057 \\
\hline Fruit/vegetable consumption ${ }^{b}$ & -0.332 & $(-0.932$ to 0.268$)$ & -1.087 & 0.277 & -0.019 \\
\hline Validity of the model & & & $F=16.7$ & $<0.001$ & $R^{2}=0.096$ \\
\hline
\end{tabular}

${ }^{a}$ Evaluated with 5-point model

${ }^{b}$ Evaluated with 3-point model; taken as ordinal variables. 
include rural residents. Additionally, the data reflected only the Yozgat Province.

As shown by relevant studies, estimated hypertension risk can be used to predict the incidence of hypertension in the community. Accordingly, provisional health policies can be developed using data for hypertension risk in the population of concern. Our study has shown that FHPRS can be applied to the population in Yozgat Province to estimate hypertension risk. Therefore, this preliminary study could pave the way for further, large studies in Turkey, and public health policies could be developed for the Turkish community accordingly.
Acknowledgements

This study was a poster presentation at the 6th European Public Health Conference, 13-16 November 2013, Brussels, Belgium and the abstract published (Eur J Public Health 2013; 23 (Suppl. 1).

\section{Funding: None.}

Competing interests: None declared.

\section{References}

1. Global status report on noncommunicable diseases 2010. Geneva: World Health Organization; 2011.

2. Turkey Health Ministry. Turkey Burden of Disease Study (TBDS) 2004. Ankara: Aydoğdu Ofset Matbaacılık San. ve Tic. Ltd. Şti; 2007:71.

3. US Preventive Services Task Force. Screening for high blood pressure: reaffirmation recommendation statement. Am Fam Physician. 2009;79(12):1087-8.

4. Kılıç M, Koç A. İl merkezindeki birinci basamak sağlık kuruluşlarına başvuranların tarama testleri yaptırma durumu ve etkileyen faktörlerin çok değişkenli analizi. [Multivariate analysis of having screening tests and factors that affect attendance the primary health care institution at city] Nobel Medicus. 2014;10(1):36-42.

5. Pereira M, Lunet N, Azevedo A, Barros H. Differences in prevalence, awareness, treatment and control of hypertension between developing and developed countries. J Hypertens. 2009;27(5):963-75. 10.1097/HJH.0b013e3283282f65

6. Türk Hipertansiyon Prevalans Çalışması PatenT2 [Turkish Hypertension Prevalence Study 2012 PatenT2]. Turkish Society of Hypertension and Kidney Diseases; 2012. (http://www.turkhipertansiyon.org/prevelans_calismasi_2.php, accessed 4 May 2016)

7. Erdem Y, Arici M, Altun B, Turgan C, Sindel S, Erbay B, et al. The relationship between hypertension and salt intake in Turkish population: SALTURK study. Blood Press. 2010;19(5):313-8. 10.3109/08037051003802541

8. Kastarinen $\mathrm{M}$, Antikainen $\mathrm{R}$, Peltonen $\mathrm{M}$, Laatikainen $\mathrm{T}$, Barengo NC, Jula A, et al. Prevalence, awareness and treatment of hypertension in Finland during 1982-2007. J Hypertens. 2009;27(8):1552-9. 10.1097/HJH.0b013e32832c41cd

9. Ünal B, Ergör G, Dinç-Horasan G, Kalaça S, Sözmen K. Blood pressure and hypertension. In: Chronic diseases and risk factors survey in Turkey. Ünal B, Ergör G, editors. Ankara: Republic of Turkey Ministry of Health; 2013:69-89.

10. Arici M, Turgan C, Altun B, Sindel S, Erbay B, Derici U, et al. Hypertension incidence in Turkey (HinT): a population-based study. J Hypertens. 2010;28(2):240-4. 10.1097/HJH.0b013e328332c36b.

11. Vasan RS, Beiser A, Seshadri S, Larson MG, Kannel WB, D'Agostino $\mathrm{RB}$, et al. Residual lifetime risk for developing hypertension in middle-aged women and men: The Framingham Heart Study. JAMA. 2002;287(8):1003-10. 10.1001/jama.287.8.1003

12. Wang NY, Young JH, Meoni LA, Ford DE, Erlinger TP, Klag MJ. Blood pressure change and risk of hypertension associated with parental hypertension: the Johns Hopkins Precursors Study. Arch Intern Med. 2008;168(6):643-8. 10.1001/archinte.168.6.643.

13. Parikh NI, Pencina MJ, Wang TJ, Benjamin EJ, Lanier KJ, Levy $\mathrm{D}$, et al. A risk score for predicting near-term incidence of hypertension: the Framingham Heart Study. Ann Intern Med. 2008;148(2):102-10. PubMed PMID: 18195335.
14. Address Based Population Registration System (ABPRS) Results [Internet]. Turkish Statistical Institute 2013 [cited 2 January 2013]. Available from: http://www.turkstat.gov.tr/PreTablo. do?alt_id=1059

15. Behavioral Risk Factor Surveillance System Questionnaire 2011 Atlanta: Centers for Disease Control and Prevention; 2011 (http:// www.cdc.gov/brfss/questionnaires/pdf-ques/2011brfss.pdf, accessed 4 May 2016)

16. Diet, nutrition and the prevention of chronic diseases: report of a joint WHO/FAO expert consultation. WHO Technical Report Series 916. Geneva: World Health Organization; 2002.

17. Chobanian AV, Bakris GL, Black HR, Cushman WC, Green LA Izzo JL Jr, et al. The Seventh Report of the Joint National Committee on Prevention, Detection, Evaluation, and Treatment of High Blood Pressure: the JNC 7 report. JAMA. 2003;289(19):2560-72. 10.1001/jama.289.19.2560

18. Kivimaki M, Batty GD, Singh-Manoux A, Ferrie JE, Tabak AG, Jokela $M$, et al. Validating the Framingham Hypertension Risk Score: results from the Whitehall II study. Hypertension. 2009;54(3):496-501.

19. Meyers LS, Gamst G, Guarino A. Applied multivariate research: design and interpretation. London: Sage; 2006

20. Huang Y, Su L, Cai X, Mai W, Wang S, Hu Y, et al. Association of all-cause and cardiovascular mortality with prehypertension: a meta-analysis. Am Heart J. 2014;167(2):160-8.el.

21. Shen L, Ma H, Xiang MX, Wang JA. Meta-analysis of cohort studies of baseline prehypertension and risk of coronary heart disease. Am J Cardiol. 2013;112(2):266-71. 10.1016/j.amjcard.2013.03.023.

22. Levine DA, Lewis CE, Williams OD, Safford MM, Liu K, Calhoun DA, et al. Geographic and demographic variability in 20-year hypertension incidence: the CARDIA study. Hypertension. 2011;57(1):39-47.

23. Fuchs FD, Gus M, Moreira LB, Moraes RS, Wiehe M, Pereira GM, et al. Anthropometric indices and the incidence of hypertension: a comparative analysis. Obes Res. 2005;13(9):1515-7. 10.1038/ oby.2005.184.

24. Lee JH, Yang DH, Park HS, Cho Y, Jun JE, Park WH, et al. Incidence of hypertension in Korea: 5-year follow-up study. J Korean Med Sci. 2011;26(10):1286-92.

25. Diseases TSoHaK. Türkiye'de Tuz Tüketimi Çalıșması SALTurk2 [Turkey Salt Consumption Study SalTurk-2]. Turkish Society of Hypertension and Kidney Diseases; 2012. http://www.turkhipertansiyon.org/ppt/SALTurk2.ppt, accessed 5 May 2016.

26. He FJ, LiJ, MacGregor GA. Effect of longer term modest salt reduction on blood pressure: Cochrane systematic review and metaanalysis of randomised trials. BMJ. 2013;346: 10.1136/bmj.f1325 